\title{
Eyelid liquoric fistula secondary to orbital meningocele
}

\section{Fístula liquórica palpebral secundária à meningocele orbitária}

Renato Antunes Schiave Germano', Mateus Violin Silva², Flávio Augusto Schiave Germano ${ }^{3}$, Michele Madeira Brandão ${ }^{2}$, Caroline Schiave Germano ${ }^{4}$, Bárbara Leite de Souza ${ }^{5}$, Rogério Masahiro Kawai ${ }^{6}$, Jorge Estéfano Germano $^{6}$

\begin{abstract}
Liquoric fistula $(L F)$ is defined as the communication of the subarachnoid space with the external environment, which main complication is the development of infection in the central nervous system. We reported the case of a patient with non-traumatic eyelid liquoric fistula secondary to orbital meningocele (congenital lesion), which main clinical manifestation was unilateral eyelid edema. Her symptoms and clinical signs appeared in adulthood, which is uncommon. The patient received surgical treatment, with complete resolution of the eyelid swelling. In conclusion, eyelid cerebrospinal fluid (CSF) fistula is a rare condition but with great potential deleterious to the patient. It should be considered in the differential diagnosis of unilateral eyelid edema, and surgical treatment is almost always mandatory.

Keywords: Meningocele; Eyelid; Edema; Magnetic resonance imaging; Anatomy; Cerebrospinal fluid; Diagnosis, differential; Case reports
\end{abstract}

\section{RESUMO}

Fístula liquórica (FL) é definida como a comunicação do espaço subaracnóide com o ambiente externo, cuja principal complicação é o desenvolvimento da infecção no sistema nervoso central. Relatamos o caso de um paciente com fístula liquórica palpebral não traumática secundária à meningocele orbitária (lesão congênita) sendo que a principal manifestação clínica foi o edema palpebral unilateral. Os sintomas e sinais clínicos da paciente apareceram apenas na idade adulta, o que é incomum. A paciente recebeu tratamento cirúrgico, com resolução completa do edema palpebral. Concluimos que fístula liquórica palpebral é uma condição rara, mas com grande potencial deletério para o paciente. Deve ser sempre considerarada no diagnóstico diferencial do edema da pálpebra unilateral, e o tratamento cirúrgico é quase sempre obrigatório.

Descritores: Meningocele; Pálpebras; Edema; Imagem por ressonância magnética; Anatomia; Líquido cefalorraquidiano; Diagnóstico diferencial; Relatos de casos

\footnotetext{
${ }^{1}$ Hospital das Clínicas, Faculdade de Medicina da Universidade de São Paulo (SP), Brazil;

${ }^{2}$ Neurosurgery Service, Hospital Beneficência Portuguesa de Bauru (SP), Brazil;

${ }^{3}$ Universidade Nove de Julho - São Paulo (SP), Brazil;

${ }^{4}$ Faculdade de Medicina da Santa Casa de São Paulo (SP), Brazil;

${ }^{5,6}$ Centro de Excelência em Oftalmologia - Bauru (SP), Brazil.
}

Study carried out at Centro de Excelência em Oftalmologia de Bauru (SP), Brazil.

The authors declare no conflicts of interest

Recebido para publicação em 20/9/2014 - Aceito para publicação em 21/10/2014

Rev Bras Oftalmol. 2015; 74 (1): 46-8 


\section{INTRODUCTION}

$\mathbf{L}$ iquoric fistula (LF) is defined as the communication of the subarachnoid space with the external environment, which main complication is the development of infection in the central nervous system ${ }^{(1)}$. The Roman physician Galen was the first to investigate the leak of cerebrospinal fluid (CSF) when he described how the fluid within the ventricles exits through the nose ${ }^{(2)}$. Anatomically, the opening can occur at the anterior skull base or temporal bone. In rare cases, the CSF may occasionally migrate to the eyelids, where there is no leakage of CSF to the external environment, but eyelid edema affected.

Ommaya et al. ${ }^{(3)}$ proposed a classification of LF, dividing them into traumatic or nontraumatic origin. Traumatic LF may be iatrogenic (post surgery) or accidental, whereas the nontraumatic can be spontaneous (idiopathic) or secondary to inflammatory, congenital or tumor lesions of the skull base, and may be related to intracranial hypertension.

Orbital meningocele is a very rare congenital abnormality in which the meninges, along with CSF, herniate into the orbit. The protrusion may occur by a defect in the bony orbital walls or, more rarely, can occur in natural openings such as sphenoid fissure or optic foramen ${ }^{(4)}$.

We reported the case of a patient with non-traumatic eyelid LF secondary to congenital lesion, which main clinical manifestation was unilateral eyelid edema.

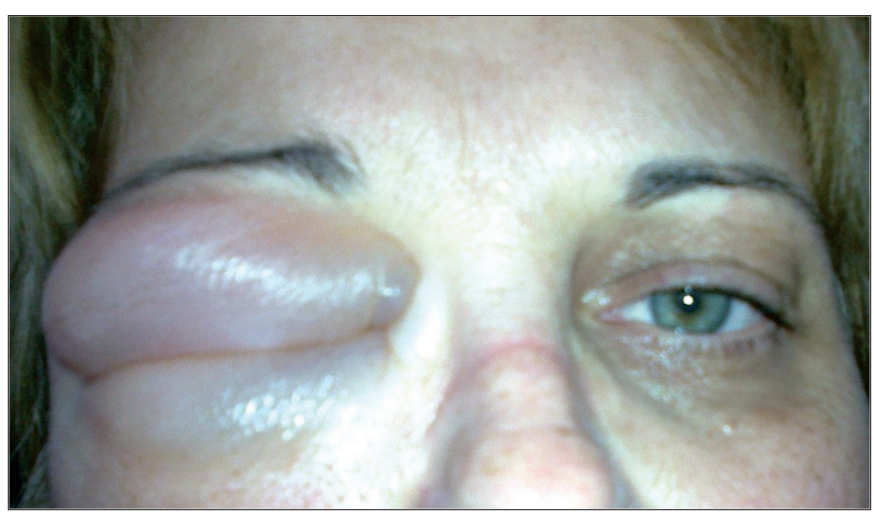

Figure 1: Clinical appearance of the patient with right eyelid edema

\section{Case Report}

A 51-years-old female patient, brazilian, white searched an ophthalmologist for the first time complaining of swelling eyelid in right eye when she awoke four days before. She presented an improvement of the edema with the course of the day. She was already using Alcaftadine, Fexofenadine, Betamethasone IM and Neomycin, Polymyxin and Dexamethasone ointment prescribed by another service, but with no improvement with that treatment (figure 1).

She referred she already had swelling in this same eye, when she woke up with spontaneous improvement with the course of the day, but she refers constant bloating four days ago.

She denied antecedents of head trauma. She was using Pantoprazol, Losartana, Metformin, Orlistat, Escitalopram and Calcium.

The ophthalmologic exam presented visual acuity 20/20 in both eyes, normal ocular motility, normal fundoscopy and anterior biomicroscopy without edema and normal intraocular pressure in both eyes.
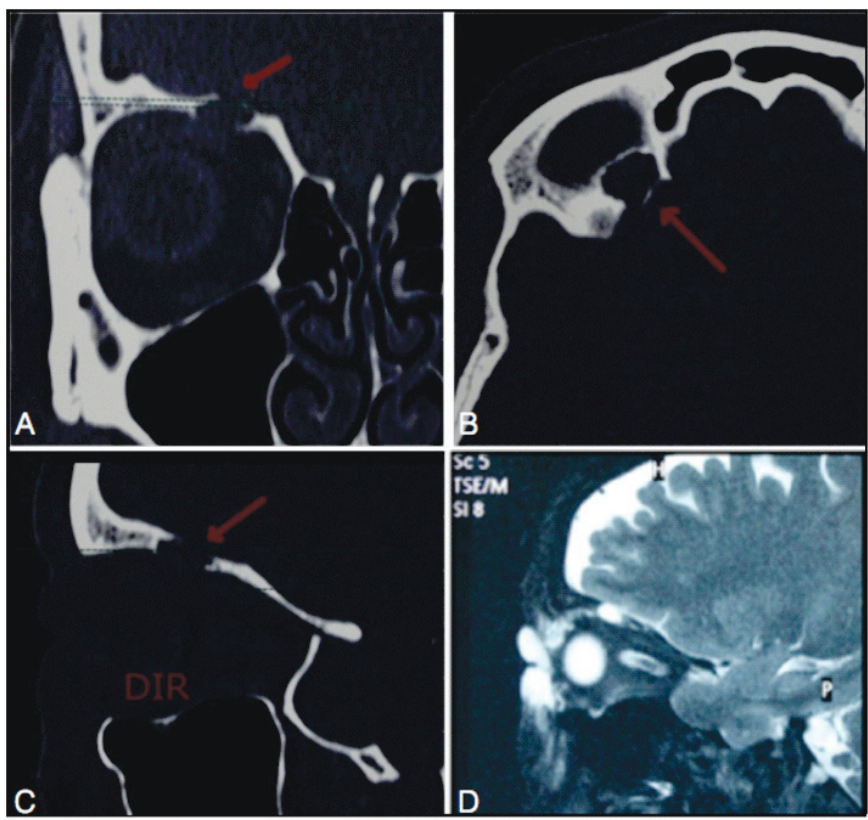

Figure 2: Tomography showing area of bone discontinuity in the right orbital roof (arrows) in coronal section (2A); axial section (2B) and sagittal section (2C); brain MRI with T2-weighted imaging in sagittal section shows the presence of CSF through the solution of bone continuity of the right orbital roof, infiltrating the eyelids (2D)

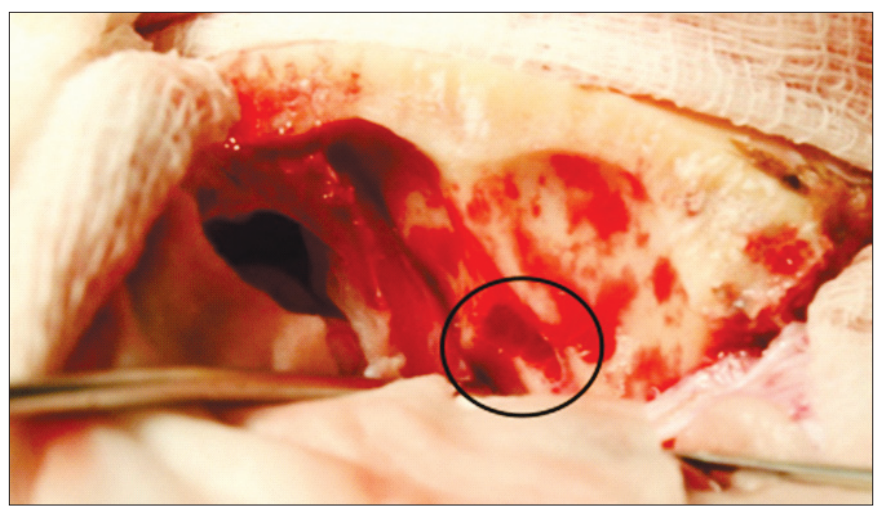

Figure 3: Intraoperative aspect showing bone defect in the right orbital roof (circle)

The dermatologist admitted the pacient, prescribing her intravenous high-dose of corticoids due to a suspicion of an allergic reaction and also she had no improvement.

Neurosurgical evaluation was requested, and neurological anamnesis did not detect a history of head injury, infections of the central nervous system or other neurological pathologies prior. On neurological examination, the patient had no focal deficits. Computed tomography $(\mathrm{CT})$ and brain magnetic resonance imaging (MRI) were performed for diagnosis.

$\mathrm{CT}$ of the brain and orbits revealed an area of bone discontinuity in the right orbital roof (figures $2 \mathrm{~A}, 2 \mathrm{~B}$ and $2 \mathrm{C}$ ). Brain MRI showed the presence of CSF through the solution of continuity of bone right orbital roof, infiltrating the eyelid tissue, without any other abnormal brain (figure 2D).

Through the clinical and neuroradiological findings, it was decided neurosurgical intervention for treatment of CSF leak through a right frontal craniotomy with subfrontal access to the right orbital roof, where the bone defect was identified with 


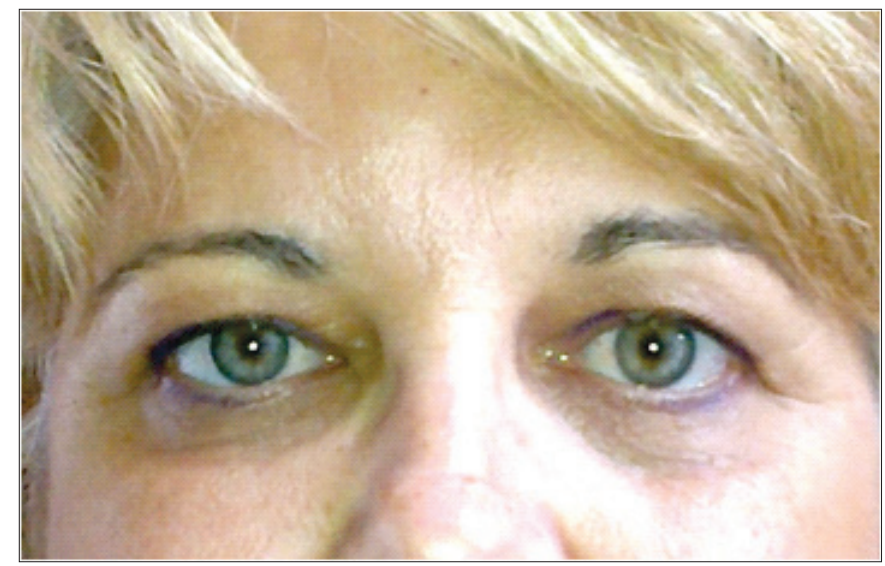

Figure 4: Image of the patient with 15-day postoperative outcome after closure of the CSF leak

overlying dural continuity solution (figure 3) confirming the diagnosis of an orbital meningocele as a source of CSF leak.

The dural opening was sutured, and then it was applied biological glue on this suture and on the area of bone defect of the right orbital roof. The immediate postoperative evolution was satisfactory, with complete regression of the right eyelid infiltration by CSF (figure 4).

Ten days after surgical procedure she presented convulsive crisis, being prescribed $100 \mathrm{mg}$ Phenytoin with clinical improvement. As sequel, she presented discreet ptosis in RE, which has been spontaneously reverted over time.

\section{Discussion}

The fistula communicating the cerebrospinal fluid (CSF) and the eyelid, also known as blepharocele, is a rare clinical manifestation $^{(5)}$ that causes eyelid swelling. It is more documented secondary trauma ${ }^{(5-7)}$, with no mention of nontraumatic form. Most cases of blepharocele have been reported in children and our case is the first reported in adults secondary to congenital orbital lesion non-traumatic blepharocele.

Ommaya et al.(3) proposed a pathophysiological explanation for the CSF non-traumatic normal pressure and without apparent cause. In this theory, called focal atrophy, cribriform structures and sela turcica could reduce volume, possibly by ischemic mechanism. The space created would be filled by CSF forming small pockets. They allow oscillation of the normal CSF pressure that creates a continuous, erosive and focal force in the skull. They have postulated also that bone defects in the skull base allow the formation of small meningeal and meningo-cerebral hernias, which, under the force of the oscillation in CSF pressure, would lead to open by forming FL. Such opening would occur in adults, considering that intracranial pressure is three times higher than in children.

Giannetti ${ }^{(8)}$ has studied CT images of 20 cases of patients with primary spontaneous cerebrospinal fluid leak (CSF) to evaluate the existence of predisposing anatomic abnormalities in the structures of the skull base. The study, however, did not show abnormalities that could characterize the FLEP.

Blepharocele clinically presents as unilateral upper eyelid edema, painless appearance transluminescence ${ }^{(7)}$. The correct diagnosis of CSF is extremely important for management, also to programming the best treatment option. In the past, spontaneous CSF was difficult to diagnose, however most recent studies have shown a higher incidence. Recently, image analyses are the gold standard for diagnosis of fistulas. Although computed tomography provide sufficient information to assess FL, MRI is the best test for diagnosis ${ }^{(9)}$ and is useful in demonstrating fractures of the orbital wall and intra-orbital CSF collection.

We could not find any reference in the literature on orbital meningocele manifesting in adulthood. In our study, the patient had never presented any changes related to cerebrospinal fluid fistula until the present moment, so this is the first described case report that describes the onset of signs and symptoms related to orbital meningocele in adulthood.

Eyelid CSF fistula is a rare condition but with great potential deleterious to the patient. It should be considered in the differential diagnosis of unilateral eyelid edema, and surgical treatment is almost always mandatory.

\section{REFERENCES}

1. Pappas DG Jr, Hammerschlag PE, Hammerschlag M. Cerebrospinal fluid rhinorrhea and recurrent meningitis. Clin Infect Dis. 1993;17(3):364-8.

2. Bongartz E B, Nau H E, Liesegang J. The cerebrospinal fluid fistula. Rhinorrhoea, otorrhoea and orbitorrhoea. Neurosurg Rev. 1981;74(1):195-200.

3. Ommaya AK, Di Chiro G, Baldwin M, Pennybacker JB. Non traumatic cerebrospinal fluid rhinorrhoea. J Neurol Neurosurg Psychiatry. 1968;31(3):214- 25.

4. Consul BN, Kulshrestha OP. Orbital meningocele. Br J Ophthalmol. 1965;49(7):374-6.

5. Bagolini B. Leakage of spinal fluid into upper lid following trauma. AMA Arch Opthalmol. 1957;57(3):454-6.

6. Bhatoe HS. Blepharocele after head injury. Skull Base. 2002;12(2):73-6.

7. Matthew JM, Haran RP, Chandy MJ. Post traumatic CSF blepharocele. Neurol India. 1997;45(1):46-7.

8. Giannetti AV.Fístula liquórica espontânea primária da base anterior do crânio: aspectos clínicos e fisiopatológicos [tese]. Belo Horizonte: Universidade Federal de Minas Gerais; 2009.

9. Chandra N, Ojha BK, Chandwani V, Srivastava C, Singh SK, Chandra A. A rare case of posttraumatic eyelid swelling: cerebrospinal fluid blepharocele. J Neurosurg Pediatr. 2013;11(3):242-4.

\section{Corresponding author:}

Renato Antunes Schiave Germano

Avenida dr. Eneas de Carvalho Aguiar, n 255

São Paulo (SP), Brazil

Phone: 55 (11) 98112-2413

Email: rasgermano@hotmail.com 